\title{
Pembinaan Minat Baca Masyarakat Melalui Pembangunan Taman Bacaan Masyarakat Desa Kemasan Klepu, Semarang, J awa Tengah
}

\author{
Muhammad Azmi Ali Sani' ${ }^{1}$, Sri Ati Suwanto ${ }^{2 *}$ \\ ${ }^{12}$ Program Studi Ilmu Perpustakaan Fakultas Ilmu Budaya, Universitas Diponegoro, \\ Jl. Prof. Soedarto, SH, Kampus Undip Tembalang, Semarang, Indonesia. \\ $\left.{ }^{*}\right)$ Korespondensi : tikasuwanto@gmail.com
}

\begin{abstract}
This research entitled "Guidance of Reading Interest of Taman Bacaan Village of Kemasan Village, Klepu, Semarang Regency of Central Java". This study aims to determine the process of fostering reading interest in the Society through the development of community reading parks in the village of packaging, Klepu, Semarang. The research design used in this research is qualitative and research type of participative action research using Action-Reflection cycle model which has 5 stages of implementation that is observation stage, reflection stage, action stage, evaluation stage, and modification stage. Data collection was done by observation method, interview, and Focus Group Discussion. After the development of community reading park and the reading interest for the children, the community in Kemasan welcome it enthusiastically. In addition, the process of developing a community reading park is not based on coercion, but solely a desire to keep the children away from a unprincipled association and also for children to have a broad insight. Community reading parks are currently working with the literacy community which is 'Tuntas' Book Community for reading interest activities. The villagers and the communities give a positive impression that they hope reading interest activities would keep continuing so that the children caan have broad insights, have central learning activities and the communities to have the opportunity to assist the villagers in meeting their information need.
\end{abstract}

Keywords: Reading park development(TBM) ; Buku Tuntas' Literacy community; Participatory Action research

\begin{abstract}
Abstrak
Penelitian ini berjudul "Pembinaan Minat Baca Masyarakat Taman Bacaan Desa Kemasan, Klepu, Kabupaten Semarang Jawa Tengah". Penelitian ini bertujuan untuk mengetahui proses pembinaan minat baca di Masyarakat melalui pembangunan taman bacaan Masyarakat di desa kemasan, Klepu, Semarang . Desain penelitian yang digunakan dalam penelitian ini adalah kualitatif dan jenis penelitian kaji tindak partisipatif dengan menggunakan model Action-reflection cycle yang memiliki 5 tahapan pelaksanaan yaitu tahap observasi, tahap refleksi, tahap tindakan, tahap evaluasi, dan tahap modifikasi. Pengumpulan data dilakukan dengan metode observasi, wawancara, dan Focus Group Disscussion. Dalam proses pembangunan taman bacaan masyarakat tidak berdasarkan paksaan, tetapi atas dasar keinginan untuk menghindarkan anak-anak ke pergaulan yang kurang baik dan juga agar anak-anak bisa memiliki wawasan yang luas. Taman bacaan masyarakat saat ini bekerja sama dengan komunitas literasi yaitu komunitas buku tuntas untuk kegiatan pembinaan minat baca. Masyarakat dan komunitas memberikan kesan positif sehingga mereka berharap agar kegiatan pembinaan minat baca terus dilanjutkan agar anak-anak memiliki wawasan yang luas, memiliki sentral kegiatan belajar dan komunitas memiliki kesempatan untuk membantu masyarakat dalam memenuhi kebutuhan informasinya.
\end{abstract}

Kata kunci: Pembangunan taman bacaan; Komunitas literasi buku tuntas; Action research partisipatif 


\section{Pendahuluan}

Membaca buku adalah jembatan untuk menambah wawasan menjadi lebih luas, pengetahuan menjadi bertambah dan kritis terhadap apa yang ada disekitarnya. Dengan perkembangan teknologi yang sangat cepat, informasi masuk silih berganti maka masyarakat akan mendapatkan berbagai macam informasi yang tidak terbendung, sehingga dengan membaca buku, maka masyarakat dapat membedakan antara informasi yang benar ataupun salah. Membaca buku juga menjadi salah satu cara untuk meningkatkan kualitas sumber daya masyarakat secara mandiri dalam menambah pengetahuan ataupun wawasan. Saat ini yang menjadi catatan bersama adalah harga buku yang masih cukup tinggi untuk kalangan masyarakat menengah ke bawah, sehingga masyarakat juga membutuhkan tempat membaca buku untuk menambah wawasan dan pengetahuan tanpa harus membeli buku. Tempat membaca ini sudah tentu menjadi catatan penting untuk pemerintah dalam memberantas masyarakat buta huruf tanpa memandang suku, ras, agama, dan status sosial-ekonomi dari tingkatan desa sampai pada tingkatan kota seperti contohnya adalah taman bacaan masyarakat.

Menurut kepala Dusun Kemasan yang bernama Pak Angsori ada sekitar kurang lebih 80\% warga Dusun Kemasan Desa Klepu Kecamatan Pringapus Kabupaten Semarang yang bekerja pada pabrikpabrik sekitar, ini sudah menjadi mindset anak muda yang berada di dusun tersebut bahwa setelah lulus SMA maka mereka akan langsung bekerja sebagai buruh pabrik di sekitar dusun tersebut. Pak Angsori juga menyampaikan keluh kesahnya kepada penulis tentang anak muda yang akan meneruskan dusunnya tersebut. Beliau memiliki visi untuk membangun masyarakatnya agar memiliki kreativitas yang lebih dan juga memaksimalkan potensi dusun yang ada sehingga anak muda yang baru lulus SMA tidak harus bekerja menjadi buruh jika perlu melanjutkan studinya. Sebab itu langkah yang diambil oleh Pak Angsori sebagai kepala dusun adalah menginginkan adanya taman bacaan masyarakat agar menjadi pusat peradaban terbangunnya kreativitas, mengenal dunia melalui bahan bacaan dan juga menjadi tempat diskusi yang bermanfaat utamanya untuk kalangan anak-anak hingga remaja.

Harapannya dengan pembangunan taman bacaan masyarakat dapat menjawab masalah pengembangan ilmu pengetahuan berkaitan dengan ketersediaanya sarana dan prasara ilmu pengetahuan, sumber informasi dan sumber penelitian. Taman bacaan masyarakat yang termasuk pada kategori perpustakaan umum harus dirancang sedemikian rupa agar diterima oleh masyarakat dengan baik dan dapat meningkatkan minat baca masyarakat. Karena itulah selain pembangunan taman bacaan masyarakat, seharusnya disertai dengan pengemasan dan strategi pembinaan minat baca masyarakat agar lebih baik lagi dalam penggunaan taman bacaan masyarakatnya.

Taman bacaan masyarakat adalah sarana untuk melayani kepentingan masyarakat yang tinggal disekitarnya terdiri dari berbagai lapisan masyarakat tanpa membedakan latar belakang baik sosial, ekonomi, budaya, agama, adat istiadat, pendidikan, umur dan lain sebagainya. Menurut Petunjuk Teknis Pengajuan dan Pengelolaan Taman Bacaan Masyarakat tahun 2012,

"Taman bacaan masyarakat adalah Lembaga pembudayaan kegemaran membaca masyarakat yang menyediakan dan memberikan layanan di bidang bahan bacaan, berupa buku, majalah, tabloid, koran, komik, dan bahan multimedia lain, yang dilengkapi dengan ruangan untuk membaca, diskusi, bedah buku, menulis, dan kegiatan literasi lainnya, dan didukung oleh pengelolayang berperan sebagai motivator."

Dari pengertian tersebut dapat dijelaskan bahwa taman bacaan masyarakat merupakan salah satu sarana berupa tempat untuk pengembangan budaya baca di masyarakat. Sutarno (2008:127) dalam bukunya menjelaskan bahwa taman bacaan masyarakat adalah tempat yang sengaja dibuat oleh pemerintah, perorangan atau swakelola, swakarsa, swadana dan swasembada oleh masyarakat yang bersangkutan.

Sedangkan menurut Buku Pedoman Penyelenggaraan Taman Bacaan Masyarakat tahun 2006 menjelaskan bahwa taman bacaan masyarakat adalah tempat / wadah yang didirikan dan dikelola baik masyarakat maupun pemerintah untuk memberikan akses layanan bacaan bagi masyarakat sekitar sebagai sarana pembelajaran seumur hidup dalam rangka peningkatan kualitas hidup di sekitar taman bacaan masyarakat.

Taman bacaan masyarakat pada jenisnya termasuk dalam kategori perpustakaan umum. Menurut Pedoman Umum Penyelenggaraan Perpustakaan Umum (1995 : 5) (dalam Sutarno, 2008) Perpustakaan 
umum yaitu Perpustakaan yang diselenggarakan di pemukiman penduduk (kota atau desa) diperuntukkan bagi semua lapisan dan golongan masyarakat penduduk pemukiman tersebut untuk melayani kebutuhan akan informasi dari bahan bacaan. Sedangkan Menurut Reitz (2004) perpustakaan umum adalah "A library Or library system that provides unrestricted acces and services free of channge to all the resident of given community, distric, or goegrapic region, supported wholly or in part by publics fund".

Sederhananya adalah perpustakaan umum merupakan perpustakaan yang menyediakan akses tidak terbatas dan gratis kepada masyarakat didaerah sekitarnya yang didukung sebagian dananya dari masyarakat dan diselenggarakan untuk menyediakan bahan bacaan, menambah informasi, pengetahuan, wawasan dan sarana untuk belajar masyarakat.

Menurut Petunjuk Teknik Pengajuan dan Pengelolaan Taman bacaan Masyarakat (2012) Penyelenggaraan Taman Bacaan Masyarakat dimaksudkan untuk menyediakan akses sarana pembelajaran yang menyediakan dan memberi layanan bahan bacaan yang merata, meluas, dan terjangkau oleh masyarakat dengan mudah dan murah.

Adapun tujuan Taman Bacaan Masyarakat adalah :

1. Meningkatkan kemampuan keaksaraan dan keterampilan membaca

2. Menumbuhkembangkan minat dan kegemaran membaca

3. Membangun masyarakat membaca dan belajar

4. Mendorong terwujudnya masyarakat pembelajar sepanjang hayat

5. Mewujudkan kualitas dan kemandirian masyarakat yang berpengetahuan, berketerampilan, berbudaya maju, dan beradab.

Dalam memenuhi peranannya sebagai sumber belajar yang dapat memfasilitasi pembelajaran seumur hidup, TBM mempunyai fungsi sebagai tempat belajar dan mencari informasi yang dibutuhkan masyarakat, baik mengenai masalah yang langsung berhubungan dengan masalah pendidikan maupun tidak berhubungan dengan pendidikan.

Menurut Buku pedoman Pengelolaan Taman Bacaan Masyarakat (2003: 2), fungsi taman bacaan masyarakat adalah :

1. Sarana pembelajaran bagi masyarakat untuk belajar mandiri, dan sebagai penunjang kurikulum program Pendidikan Luar Sekolah, khususnya program keaksaraan.

2. Sumber informasi yang bersumber dari buku dan bahan bacaan Iainnya yang sesuai dengan kebutuhan warga belajar dan masyarakat setempat.

3. Sumber penelitian dengan menyedikan buku-buku dan bahan bacaan Iainnya dalam studi kepustakaan.

4. Sumber rujukan yang menyediakan bahan referensi bagi pembelajaran dan kegiatan akademik Iainnya.

5. Sumber hiburan (rekreatif) yang menyediakan bahan-bahan bacaan yang sifatnya rekreatif untuk memamfaatkan waktu senggang untuk memperoleh pengetahuan/informasi baru yang menarik dan bermamfaat.

Taman bacaan masyarakat berperan sebagai sumber informasi dan sarana belajar yang penting untuk menambah pengetahuan dan wawasan serta membangun komunitas antara sesama pengguna taman bacaan masyarakat lainnya.

Menurut Sutarno NS (2006: 68) peran yang dapat dijalankan taman bacaan masyarakat antara lain:Secara umum taman bacaan masyarakat merupakan sumber informasi, pendidikan, penelitian, observasi, dan pelestarian khasanah budaya bangsa serta tempat rekreasi sehat, murah, dan bermanfaat.

a. Mempunyai peran media atau jembatan yang berfungsi menghubungkan antara sumber informasi dan ilmu pengetahuan yang terkandung di dalam koleksi yang dimiliki.

b. Mempunyai peran sebagai sarana untuk menjalin dan mengembangkan komunikasi antarsesama pemakai, dan antara penyelenggara taman bacaan masyarakat dengan masyarakat lainnya.

c. Dapat berperan sebagai lembaga untuk membangun minat baca, kegemaran membaca, kebiasaan membaca, dan budaya membaca, melalui penyedia berbagai bahan bacaan yang sesuai dengan kebutuhan masyarakat.

d. Berperan aktif sebagai fasilitator, mediator, motivator bagi mereka yang ingin mencari, memanfaatkan, mengembangkan ilmu pengetahuan dan pengalamannya.

e. Merupakan agen perubahan, agen pembangunan, dan agen kebudayaan masyarakat. 
f. Berperan sebagai lembaga pendidikan nonformal bagi anggota masyarakat dan penunjang taman bacaan masyarakat. Mereka dapat mandiri (otodidak), melakukan penelitian, menggali, memanfaatkan dan mengembangkan sumber informasi dan ilmu pengetahuan.

g. Petugas taman bacaan masyarakat dapat berperan sebagai pembimbing dan memberikan konsultasi kepada pemakai atau melakukan pendidikan (user education), dan pembinaan serta menanamkan pemahaman tentang pentingnya taman bacaan masyarakat bagi orang banyak.

h. Menghimpun dan melestarikan koleksi bahan pustaka agar tetap dalam keadaan baik semua karya manusia yang tidak ternilai harganya.

Pembangunan taman bacaan masyarakat tidak hanya sebatas membangun sebuah gedung maupun ruangan, tetapi perlu adanya alasan yang jelas dan tegas untuk apa pembangunan taman bacaan masyarakat diadakan. Ada hal untuk diketahui lebih mendalam tentang pembangunan taman bacaan masyarakat yaitu dalam rangka membangun masyarakat membaca untuk mewujudkan masyarakat pembelajar sepanjang hayat, mengikuti arah kebijakan Pembangunan Pendidikan Nasional 2010-2014 yang tertuang pada Peraturan Menteri Pendidikan Nasional No.48 Tahun 2010 yaitu penguatan dan perluasan budaya melalui penyediaan taman bacaan masyarakat, bahan bacaan dan sumber informasi lain yang mudah, murah, dan merata.

Sebagai penguatan tentang konsep pembangunan taman bacaan masyarakat maka perlu dijabarkan penjelasan tentang taman bacaan yang termasuk pada perpustakaan umum. Blasius Sudarsono (2006: 157) dalam Firmansyah (2009: 12) secara skeptik mengajukan pertanyaan sebagai berikut:

"Awal program pembangunan perpustakaan umum pasca kemerdekaan Republik Indonesia terjadi pada dasawarsa 1950-an, tepatnya pada bulan April tahun 1953, bersamaan dengan didatangkannya konsultan Unesco dari Selandia Baru, yaitu Mr. A.W.G. Dunningham (Williamson, 1999). Pada waktu itu dapat dikatakan bahwa hanya 10\% masyarakat kita telah bebas buta huruf. Angka ini diperhatikan, karena pada waktu proklamasi kemerdekaan Indonesia sering disebut bahwa masyarakat masih $90 \%$ buta huruf. Pendekatan pembangunan perpustakaan dengan konsultan asing itu dapat diduga menggunakan pola pikir masyarakat barat yang sudah memiliki kebiasaan membaca dengan baik. Dengan demikian dapat dipertanyakan apakah perpustakaan yang dibangun pada waktu itu ditujukan juga untuk $90 \%$ masyarakat yang masih buta huruf atau hanya untuk 10\% masyarakat melek huruf."

Namun pada kelanjutannya yang terjadi adalah "banyak orang yang menganggap bahwa perpustakaan lebih banyak dikunjungi oleh mereka yang merasa butuh ilmu pengetahuan terutama pelajar dan mahasiswa serta dosen atau peneliti” (Rusmana, 1996: 162). Jika anggapan seperti itu yang beredar pada masyarakat, maka sudah tentu masyarakat masih memandang bahwa perpustakaan umum hanya untuk segolongan tertentu. Blasius (2006: 158) dalam Firmansyah (2009) menyatakan "dapat diduga bahwa semua jenis perpustakaan yang saat ini kita kembangkan dan kelola nampaknya terjerumus hanya berguna bagi golongan elite."

Terkait dengan dugaan tersebut, Anuar (1981: 80) dalam Firmansyah (2009) menjelaskan bahwa pada masyarakat yang dikatakan sebagai buta huruf kemungkinan akan sangat kecil mengunjungi perpustakaan umum karena di antara mereka yang beranggapan perpustakaan umum tidak memiliki koleksi yang sesuai dengan kebutuhan mereka atau yang dapat mereka gunakan. Demikian pula dengan orang yang dikategorikan tidak mampu tidak dapat menyediakan waktu dan biaya untuk bergabung dengan perpustakaan umum. Perpustakaan umum yang ada masih banyak mengandalkan sumber pendanaannya pada iuran anggota serta dari dana pemerintah daerah. Lebih lanjut, Anuar pada dasarnya melihat sistem perpustakaan umum di beberaoa Negara berkembang telah dikembangkan dengan cukup baik. Akan tetapi, dalam pelaksanaannya perpustakaan yang ada memiliki kecenderungan melayani hanya pada masyarakat elit, yaitu masyarakat yang berpendidikan tinggi dimana kelompok masyarakat ini juga memiliki kemudahan dalam mengakses jenis perpustakaan lainnya.

Berdasarkan uraian diatas, maka penulis tertarik untuk mengadakan penelitian dengan judul "Pembangunan Taman Bacaan Masyarakat Sebagai Sarana Pembinaan Minat Baca Masyarakat (Kaji Tindak Partisipatif di Dusun Kemasan, Desa Klepu, Kabupaten Semarang, Jawa Tengah)".Rumusan masalah penelitian ini adalah bagaimana sistem manajemen arsip kartografi dan kearsitekturan dalam upaya pemenuhan kebutuhan informasi geografis peneliti di Dinas Kearsipan dan Perpustakaan Provinsi Jawa Tengah?. Adapun tujuan penelitian ini adalah sebagai berikut:

Bagaimana tahap dan proses pembangunan taman bacaan masyarakat sebagai sarana pembinaan minat baca masyarakat? 


\section{Metode Penelitian}

Penelitian ini menggunakan desain penelitian kualitatif dengan pendekatan penelitian kaji tindak. Menurut Moleong (2013: 6), penelitian kualitatif adalah penelitian yang bermaksud tentang memahami fenomena apa yang dialami subjek penelitian misalnya perilaku, persepsi, motivasi, tindakan, dll. Maka, hasil dalam penelitian ini disampaikan secara kualitatif dengan mengumpulkan data berupa kata yang diperoleh dari hasil wawancara, gambar dari hasil foto keterlibatan secara langsung saat penelitian dan pengamatan kejadian secara langsung di tempat penelitian. Data yang sudah terkumpul maka selanjutnya dimaknai dan dipahami secara mendalam.

Jenis penelitian ini yaitu menggunakan jenis penelitian kaji tindak atau yang dikenal sebagai action research. Metode ini merupakan rancangan praktis untuk penelitian terapan. Menurut Cresswell dalam Yaumi dan Damopoli (2014: 14) penelitian tindakan atau kaji tindak terbagi dalam dua tipe, yaitu penelitian tindakan praktis dan penelitian tindakan partisipatorik. Penelitian tindakan praktis meliputi proyek penelitian berskala kecil terhadap masalah yang terjadi pada suatu tempat. Adapun penelitian tindakan partisipatorik adalah menyelidiki isu sosial yang melibatkan masyarakat, perusahaan, dan organisasi lainnya di luar dari institusi pendidikan Maka, sesuai dengan permasalahan yang ada didalamnya, penelitian ini menggunakan tipe partisipatorik. Partisipatorik yang dilakukan adalah pembangunan taman bacaan sebagai sarana pembinaan minat baca masyarakat. Pembangunan dan pelaksanaan taman bacaan masyarakat sebagai sarana pembinaan minat baca ini melibatkan perangkat dusun, masyarakat dan juga komunitas gerakan literasi. Adanya sarana pembinaan minat baca adalah memiliki tujuan memberikan pelayanan dan tempat untuk saling berdiskusi juga bercerita tentang pentingnya membaca untuk membuka pengetahuan yang lebih luas tentang dunia. Dalam pelaksanaannya, penelitian ini menggunakan model An Action-Reflection Cycle yang dibuat oleh McNiff dan Whitehead (Putra, 2014: 32).

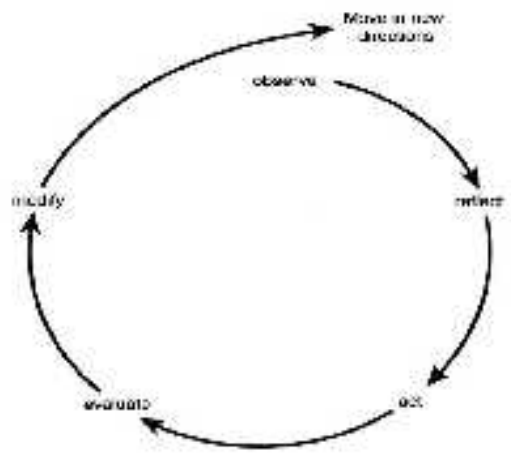

Bagan 1. Desain An Action-Reflection Cycle

Jenis data sebagai informasi yang tepat perlu ditentukan oleh peneliti guna mencapai tujuan penelitian. Jenis data dibutuhkan karena dapat membantu peneliti dalam menciptakan pertanyaan yang sesuai dengan kebutuhan penelitian. Jenis data yang digunakan dalam penelitian ini adalah data kualitatif.Peneliti menggunakan data kualitatif berupa sumber primer dan sumber sekunder.Teknik yang digunakan oleh peneliti untuk mendapatkan sumber primer antara lain dengan melakukan observasi, wawancara dan dokumentasi.Sumber primer adalah sumber data yang secara langsung memberikan data kepada pengumpul data. Sumber sekunder yang digunakan oleh peneliti berupa buku, dan jurnal, skripsi, Undang-Undang yang berhubungan dengan topik penelitian.Peneliti menggunakan sumber sekunder dengan tujuan untuk memperkuat penelitian dan melengkapi informasi penelitian.Sumber data sekunder ini dapat berupa hasil pengolahan lebih lanjut dari data primer yang disajikan dalam bentuk lain atau dari orang lain (Sugiyono, 2012:225).

Subjek merupakan orang yang melakukan sesuatu (Sugiyono, 2015: 74). Subjek dalam penelitian ini adalah perangkat dusun, masyarakat dan juga komunitas literasi yang turut melaksanakan berdirinya taman bacaan juga proses pembinaan minat baca di masyarakat. Hal ini dikarenakan oleh setiap hasil wawancara yang diperoleh dari informan perangkat dusun, masyarakat dan juga komunitas literasi tersebut akan menjadi sumber utama dalam penelitian dan hasil penelitian ini akan disimpulkan juga kepada perangkat dusun, masyarakat dan juga komunitas literasi.Objek penelitian menurut Sugiyono 
(2012: 13) bahwa "objek penelitian adalah sasaran ilmiah untuk mendapatkan data dengan tujuan dan kegunaan tertentu tentang suatu hal objektif, valid, dan reliable tentang suatu hal (variabel tertentu)".

Subjek merupakan orang yang melakukan sesuatu (Sugiyono, 2015: 74). Subjek dalam penelitian ini adalah perangkat dusun, masyarakat dan juga komunitas literasi yang turut melaksanakan berdirinya taman bacaan juga proses pembinaan minat baca di masyarakat. Hal ini dikarenakan oleh setiap hasil wawancara yang diperoleh dari informan perangkat dusun, masyarakat dan juga komunitas literasi tersebut akan menjadi sumber utama dalam penelitian dan hasil penelitian ini akan disimpulkan juga kepada perangkat dusun, masyarakat dan juga komunitas literasi.

Teknik pengumpulan data merupakan hal yang perlu dipahami oleh peneliti guna mendapatkan data-data yang sesuai dengan yang dibutuhkan dalam menyelesaikan penelitian. Pengumpulan data penelitian dapat dilakukan dengan beberapa cara yang tepat. Menurut Sugiyono (2012: 225), macam teknik pengumpulan data terdiri dari observasi, wawancara, diskusi kelompok, dan triangulasi/gabungan. Teknik pengumpulann data yang digunakan oleh peneliti antara lain yaitu:

1. Observasi

Observasi dilakukan untuk mendekatkan peneliti ke orang-orang yang ditelitinya dan ke situasi atau lingkungan mereka yang sebenarnya. Creswell (2015:422)juga menjelaskan bahwa observasi merupakan proses dari suatu pengumpulan informasi terbuka (open-ended) tangan pertama dengan cara mengobservasi atau mengamati orang dan tempat di suatu lokasi penelitian.

2. Wawancara

Wawancara adalah percakapan yang dilakukan oleh dua pihak yaitu pewawancara (interviewer) yang mengajukan pertanyaan dan terwawancara (interviewee) yang memberikan jawaban atas pertanyaan (Moleong, 2012:118). Dengan menggunakan wawancara ini peneliti lebih bisa memahami apa yang terjadi dan dapat sesuai dengan informasi yang di butuhkan oleh peneliti.

3. Dokumentasi

Diskusi kelompok dilakukan bersama para partisipan yang telah disebutkan di atas (kecuali kepala dusun) untuk menganalisis data dan informasi yang dikolaborasikan terkait dengan pengkajian, perencanaan dan pelaksanaan pembangunan taman bacaan masyarakat sebagai sarana pembinaan minat baca masyarakat. di dalam diskusi kelompok, peneliti juga berperan sebagai fasilitator.

Penelitian ini menggunakan informan sebagai sumber data penelitian. Peneliti tidak menggunakan populasi dan sampel karena jenis penelitian adalah kualitatif. Informan sebagai sumber informasi akan memberikan gambaran, bukti dan keadaan nyata berupa jawaban dari hasil wawancara.Adapun yang dimaksud informan dalam penelitian adalah seseorang yang benar-benar mengetahui suatu persoalan atau permasalahan tertentu yang darinya dapat diperoleh informasi yang jelas, akurat, dan terpercaya (Moleong, 2000:97).

Informan yang peneliti pilih adalah informan yang terlibat dalam kegiatan pembangunan taman bacaan masyarakat sebagai sarana pembinaan minat baca masyarakat. Pemilihan informan menggunakan teknik purposive sampling yaitu teknik pengambilan sampel sumber data dengan pertimbangan tertentu.Adapun kriteria yang telah ditentukan sebagai berikut:

1. Merupakan Perangkat Dusun;

2. Merupakan Anggota Komunitas Literasi

3. Masyarakat Dusun yang pernah menggunakan taman bacaan masyarakat.

Sugiyono (2008: 246) mengungkapkan bahwa analisis data pada penelitian kualitatif dilakukan saat proses pengumpulan data di lapangan, dan setelah selesai melakukan pengumpulan data dalam suatu periode tertentu. Miles and Huberman (1984) dalam Sugiyono mengemukakan bahwa aktivitas dalam melakukan analisis data kualitatif dilakukan secara intensif dan terus menerus hingga tuntas, sehingga data yang dihasilkan jenuh, Berikut adalah model analisisnya :

a) Reduksi Data (Data Reduction)

Reduksi data artinya merangkum, memilih poin-poin pokok, memfokuskan suatu hal yang dianggap penting, dan mencari tema serta pola. Data yang telah direduksi, akan memberikan memudahkan peneliti serta memberikan gambaran yang jelas ketika akan melakukan pengumpulan data selanjutnya.

b) Penyajian Data (Data Display)

Penyajian data pada penelitian kualitatif dapat dilakukan dalam bentuk uraian yang singkat, bagan, flowchart, hubungan antar kategori dan sejenisnya. Namun yang paling banyak digunakan dalam penyajian data kualitatif yaitu dengan menggunakan teks naratif. Display data digunakan supaya 
dapat memudahkan untuk memahami sesuatu yang terjadi, dan untuk merencanakan langkah kerja selanjutnya berdasarkan apa yang telah dipahami.

c) Verifikasi (Verification)

Tahap akhir pengolahan data adalah penarikan kesimpulan. Setelah semua data tersaji permasalahan yang menjadi objek penelitian dapat dipahami dan kemudian ditarik kesimpulan yang merupaan hasil dari penelitian ini.

Uji keabsahan atau validitas pada penelitian kualitatif merupakan upaya pemeriksaan terhadap keakuratan hasil penelitian dengan menerapkan prosedur tertentu (Creswell, 2014: 285). Menurut Creswell (2014: 286), validitas ini didasarkan pada suatu kepastian apakah hasil penelitian yang dilakukan oleh peneliti sudah akurat dari sudut pandang si peneliti, partisipan, ataupun pembaca secara umum.

Ada beragam strategi yang digunakan dalam validitas pada penelitian kualitatif. Strategi validitas yang digunakan oleh peneliti yaitu dengan mentriangulasi (triangulate) sumber-sumber data yang berbeda. Pada penelitian ini langkah yang dilakukan untuk memvalidasi keakuratan hasil temuan dengan menggunakan triangulasi. Terdapat tiga macam triangulasi diantaranya triangulasi sumber, teknik, dan waktu. Dari ketiga macam triangulasi tersebut, peneliti menggunakan triangulasi teknik. Triangulasi teknik untuk menguji kredibilitas data dilakukan dengan caramengecek data kepada sumber yang sama dengan teknik yang berbeda (Sugiyono, 2015: 127).

\section{Hasil dan Pembahasan}

\subsection{Pembangunan Pembangunan Taman Bacaan Masyarakat}

Hasil dan Pembahasan disajikan dari data yang diperoleh selama proses kegiatan pembangunan taman bacaan masyarakat sebagai sarana pembinaan minat baca masyarakat. Data kualitatif yang disajikan dan dianalisis adalah hasil dari proses pembangunan taman bacaan dan pembinaan minat baca masyarakat yang diambil dengan cara wawancara kepada informan yang dilakukan secara terbuka dengan Focus Grup Interview ditambah dengan data hasil observasi, dan Fokus Grup Diskusi (FGD).

Pada bagian ini juga membahas paparan dari proses dan hasil kaji tindak partisipatif pembangunan taman bacaan masyarakat sebagai sarana pembinaan minat baca masyarakat melibatkan partisipasi masyarakat di dusun kemasan sebagai perspektif partisipan/informan yang telah diklasifikasikan pada tahapan-tahapan pembangunan taman bacaan masyarakat sebagai sarana pembinaan minat baca, dan disajikan sesuai tahapan kaji tindak partisipatif.

Selain itu, pada bagian ini juga menjelaskan dengan cara menyajikan narasi yang telah dikumpulkan selama proses penelitian berupa deskripsi atau keterangan secara rinci yang ditemukan di lapangan serta berbagai perspektif partisipan/informan, sehingga memungkinkan pembaca lebih mudah memahami dengan penuh empati realitas pengalaman dan pandangan partisipan/informan terhadap tahapan-tahapan pembangunan taman bacaan masyarakat yang mengikutsertakan partisipasi masyarakat. Setiap penyajiannya, tahapan-tahapan yang dilalui disederhanakan menjadi (1) tahap observasi, (2) tahap perencanaan dan persiapan, (3) tahap pelasaksanaan pembangunan dan pembinaan, dan (4) tahap evaluasi yang lebih ditekankan pada faktor pendukung dan penghambat dari proses yang telah dilalui pada pembangunan taman bacaan masyarakat sebagai sarana pembinaan minat baca masyarakat dan ditinjau dari implementasi desain penelitian

Berbagai macam informasi dikumpulkan oleh peneliti. Dimulai dari tahap observasi, yaitu saat kegiatan kuliah kerja nyata peneliti sudah mulai mengamati secara langsung bagaimana kondisi lingkungan yang ada disekitarnya dan berdiskusi secara singkat dengan warga yang terdapat di dusun tersebut karena ada salah satu teman yang harus melakukan program kuliah kerja nyata disana. Saat itu program yang dilakukan adalah tentang sosialisasi pembuatan alat untuk mengusir nyamuk dengan bunga lavender. Peneliti mengikuti program tersebut sekaligus melihat kondisi warganya dan peneliti hanya melakukan pengamatan saja.

Setelah melakukan pengamatan dusun secara penglihatan peneliti, maka peneliti mulai berdiskusi dengan salah satu warga dusun yang saat itu peneliti di ajak untuk ikut rembug tentang agenda-agenda dusun selama satu tahun ke depan, dan ini termasuk pada bagian perencanaan pembangunan taman bacaan masyarakat. Di agenda rembug tersebut, peneliti menanyakan kepada salah satu warga bagaimana kondisi masyarakatnya tentang komunikasi antar warganya, perangkat dusunnya dan pekerjaannya. Dari 
diskusi sederhana yang dilakukan peneliti, Peneliti hanya mendapatkan informasi yang sederhana yaitu pekerjaan masyarakat disana macam-macam, warga disana komunikasinya masih baik dan perangkat dusunnya baru menjabat kurang lebih 2 bulan.

Dalam proses pembangunan sebuah bangunan pada hakikatnya memerlukan pengkajian, perencanaan dan sosialisasi agar tidak terdapat kesalahan maupun kesalahpahaman antara pihak yang membangun dan pihak yang berada disekitar daerah pembangunan tersebut. Hal tersebut juga terdapat pada proses pembangunan taman bacaan masyarakat di Dusun Kemasan. Peneliti mengkaji, merencanakan dan melakukan sosialisasi kepada masyarakat terkait proses pembangunan taman bacaan masyarakat yang akan digunakan sebagai sarana pembinaan minat baca masyarakat agar tidak memiliki kesalahan perspektif yang terjadi di masyarakat saat proses keberjalanan pembangunannya nanti. Dahulu pada saat kegiatan kuliah kerja nyata, peneliti tidak melakukan pengkajian, perencanaan dan sosialisasi yang matang sehingga mengharuskan peneliti mengkaji, merencanakan dan sosialisasi kembali.

Pada proses pengkajian, peneliti melakukannya dengan cara focus group discussion yang terdiri dari 3 informan yaitu Pak Angsori, Pak Arif dan Pak Sholihin untuk menggali informasi terkait harapan jika nantinya terdapat taman bacaan di Dusun Kemasan. Dengan adanya harapan yang disampaikan dalam hal ini oleh informan, maka peneliti dapat mengkaji terkait nantinya program-program yang terdapat pada taman bacaan masyarakat bisa lebih diterima dan disambut antusias oleh informan khususnya dan masyarakat pada umumnya.

Perencanaan dibuat dari hasil analisis harapan yang didapatkan di lapangan, peneliti melakukan sosialisasi kepada masyarakat tentang rencana pembangunan taman bacaan masyarakat sekaligus menyampaikan terkait dengan apa saja yang perlu dilakukan oleh masyarakat terkait dengan adanya aktifitas pembangunan taman bacaan masyarakat ini. Di kesempatan ini, peneliti diberikan tempat untuk menyampaikan sosialisasi taman bacaan masyarakat pada agenda rutinan yang dilaksanakan oleh masyarakat bertempat di rumah kepala dusun Kemasan. Dalam pelaksanaan sosialisasi yang ada, masyarakat yang hadir kurang lebih sekitar 40 orang. Dalam agenda tersebut, peneliti menyampaikan terkait dengan adanya niat untuk membantu Dusun Kemasan dalam pembangunan taman bacaan masyarakat. Peneliti juga menyampaikan bahwa saat ini taman bacaan masyarakat akan ditempatkan terlebih dahulu di masjid dusun.

Dalam kesempatan tersebut juga, masyarakat ada yang mengusulkan agar taman bacaan masyarakat bisa ditempatkan pada balai dusun yang proses pembangunannya akan dilakukan pada tahun 2018. Dan pada kesempatan itu pula kepala dusun menjawab akan dipertimbangkan dan kemungkinan besar bisa terealisasi karena balai dusun ke depan akan menjadi sentral kegiatan bagi masyarakat. Namun yang terpenting saat ini adalah proses pelaksanaannya terlebih dahulu. Pada kesempatan sosialisasi ini, peneliti juga menyampaikan kepada masyarakat untuk turut membantu dan mendukung aktifitas taman bacaan yang terdapat di dusun kemasan dan masyarakat menyambut positif ajakan tersebut.

Awalnya peneliti hanya berniat untuk mencarikan donasi buku untuk kebutuhan masyarakat, tetapi kemudian peneliti bertanya kepada kepala dusun setelah buku didapatkan akan ditempatkan dimana bukubukunya dan bagaimana anak-anak disini mendapatkan akses membacanya. Kepala dusun sudah terpikirkan untuk menempatkan buku-bukunya di masjid. Sehingga dari hasil pikiran kepala dusun untuk menempatkan bukunya di masjid, peneliti mengajukan ide untuk dibuatkan taman bacaan saja untuk masyarakat dan kepala dusun pun menyetujuinya. Hal tersebut disesuaikan dengan tujuan dari kepala dusun yang menginginkan anak-anak dusun memiliki akses dan tempat untuk menambah wawasan agar kelak menjadi manusia yang berguna bagi agama, bangsa, dan negara melalui membaca yang dapat membuka wawasan. 
Setelah peneliti mendapatkan jawaban tentang penempatan buku dan persetujuan untuk mendirikan taman bacaan masyarakat, peneliti mulai melakukan pembuatan kampanye penggalangan dana melalui kitabisa.com (situs penggalangan dana secara online) dan membuat proposal untuk mengajukan pengadaan buku kepada komunitas pengadaan buku, perpustakaan daerah dan donator-donatur lainnya, dan ini termasuk sudah pada tahap pembangunan taman bacaan masyarakat. Berbagai macam cara ditempuh oleh peneliti agar mendapatkan pendanaan dan pengadaan buku secara maksimal sehingga keinginan dan mimpi kepala dusun dalam memberikan kesempatan masyarakatnya untuk belajar dan berpengetahuan luas bisa terwujud. Setelah proses pembuatan kampanye penggalangan dana dan buku selesai, peneliti mulai menghubungi beberapa komunitas dan kontak yang bisa membantu dalam proses

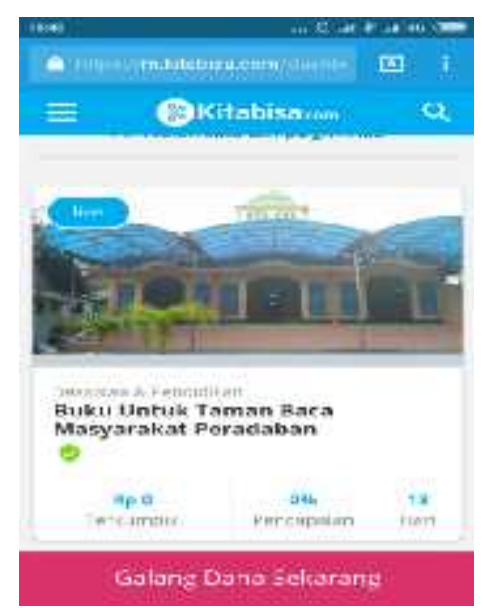

penggalangan dananya secara maksimal. Hal tersebut juga dibantu oleh teman-teman yang waktu itu berada dengan peneliti saat sedang pelaksanaan program kegiatan kuliah kerja nyata.

\section{Gambar 1. Kampanye Penggalangan Dana melalui Situs Online Kitabisa.com.}

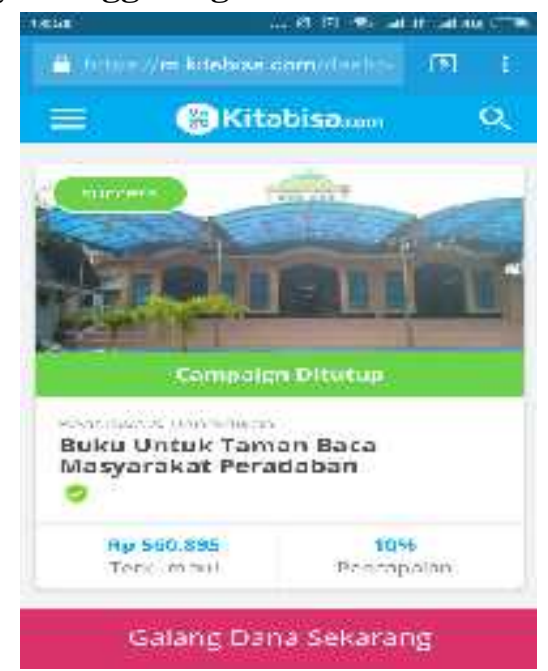

Gambar 2. Kampanye Penggalangan Dana melalui Situs Online Kitabisa.com.

Setelah melakukan proses penggalangan dana dan pengadaan buku, maka peneliti melakukan proses diskusi lebih lanjut dengan kepala dusun dan perangat dusun setempat untuk melaporkan progres penggalangan dana dan pengadaan buku. Peneliti terus melakukan koordinasi dan komunikasi secara intens sehingga kepala dusun pun selalu mencoba membantu mempublikasikan setiap kegiatan penggalangan dana dan pengadaan buku yang dilakukan oleh peneliti di akun media sosialnya. Ketika proses penggalangan dana dan pengadaan buku berjalan, peneliti juga mencoba membuat konsep terkait dengan pembangunannya nanti. 
Dan yang terpikirkan oleh peneliti adalah penyerahan secara simbolis terlebih dahulu hingga nanti dikemudian hari peneliti dapat melanjutkan program taman bacaan ini dengan baik, ide tersebut disambut baik oleh kepala dusun dan perangkatnya yang juga memikirkan hal tersebut sekaligus membantu memberikan ide dan gagasannya dalam hal peresmian secara simbolis.

Setelah berbagai proses dilakukan dalam penggalangan dana dan pengadaan buku untuk pembangunan taman bacaan masyarakat. maka secara simbolis peneliti meresmikan pembangunan taman bacaan masyarakat kepada kepala dusun dan anak-anak pada saat kegiatan pengajian yang rutin dijalankan oleh anak-anak dan sekaligus sebagai agenda pamit kepada masyarakat Dusun Kemasan yang telah bersedia menerima kegiatan kuliah kerja nyata yang dilakukan oleh mahasiswa Undip. Hal tersebut diabadikan dan diberitakan kepada masyarakat dusun baik melalui lisan ataupun media sosial oleh kepala dusun. Semua agenda berjalan dengan lancar dan taman bacaan masyarakat Dusun Kemasan mulai hari itu bisa dilaksanakan dengan dan atau tanpa peneliti.

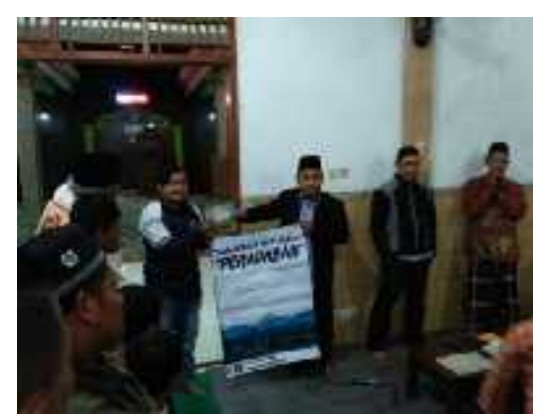

\section{Gambar 3. Penyerahan Donasi Buku dan Peresmian Simbolis Pembangunan Taman Bacaan Masyarakat.}

Dalam penggalangan dana untuk donasi taman bacaan masyarakat, Peneliti pada saat itu mendapatkan total donasi yang berbentuk dana berupa uang tunai sebesar Rp. 1.335.000 yang didapatkan dari situs online kitabisa.com dan dari donatur di luar situs online. Sedangkan donasi berupa buku didapatkan 2 dus buku dari komunitas buku untuk negeri yang berada di Bandung, 2 dus buku dari teman yang memiliki banyak koleksi buku, dan 1 dus buku yang didapatkan dari anggota kuliah kerja nyata desa klepu tahun 2016.

\subsection{Sarana Pembinaan Minat Baca Masyarakat}

Saat proses sosialisasi dan mencari tahu tentang partisipasi yang dilakukan oleh masyarakat terhadap pembangunan taman bacaan masyarakat, peneliti sudah mulai mencari partner untuk proses pembangunan taman bacaan masyarakat dan lebih fokusnya terhadap pembinaan minat baca yang akan dilakukan setelah proses pembangunan taman bacaan selesai. Segala cara dilakukan peneliti untuk mencari partner dalam membina minat baca masyarakat, mulai dari mengajak beberapa himpunan mahasiswa yang akan mengadakan program live in, kuliah kerja nyata dari universitas lain hingga akhirnya mendapatkan komunitas literasi yang bergerak di media sosial untuk terjun langsung di masyarakat. komunitas itu bernama komunitas buku tuntas.

Dalam kesempatan ini, peneliti melakukan kerjasama dengan komunitas buku tuntas untuk melakukan program pembinaan minat baca yang berkelanjutan. Peneliti memiliki aktivitas lain juga yang cukup menguras waktu dan peneliti menyadari ada kelemahan jika dalam proses pembinaan minat baca dilakukan seorang diri, sehingga peneliti berusaha semaksimal mungkin untuk mencari partner dalam proses pembinaan minat baca di masyarakat Dusun kemasan.

Harapan peneliti dengan adanya kerjasama ini, taman bacaan masyarakat bisa terus bertumbuh dan menjadi lebih baik lagi sehingga taman bacaan ini kelak bisa melahirkan banyak orang-orang yang berpendidikan dan berpengetahuan luas. Dari kerjasama ini komunitas buku tuntas menjadi pilihan peneliti setelah beberapa kali peneliti melakukan ajakan dengan berbagai komunitas maupun masyarakat.

Selain itu, peneliti dan juga komunitas memiliki arah dan visi yang sama yaitu menumbuhkan jiwa literasi masyarakat hanya saja masing-masing dari peneliti dan komunitas memiliki cara yang berbeda. Harapan peneliti dengan kolaborasi atau kerjasama yang dihasilkan nantinya, dapat melahirkan penerus yang merupakan asli masyarakat Dusun Kemasan agar pengembangannya bisa menjadi lebih baik lagi. 
Pada kesempatan ini, peneliti melakukan wawancara kepada pendiri komunitas literasi ini berkaitan tentang hal-hal mengenai komunitas buku tuntas itu sendiri.

Pelaksanaan kegiatan taman bacaan masyarakat adalah setiap minggu tepatnya di hari Minggu. Anak-anak setiap minggu bisa mengunjungi taman bacaan yang berada di masjid untuk bisa mendapatkan akses baca buku yang mereka suka. Sementara buku bacaan yang ada masih belum terlalu banyak, tapi cukup jika disesuaikan dengan jumlah anak-anak yang kurang lebih mencapai 30an anak. Kegiatan taman baca terus dilaksanakan dengan dan atau tanpa adanya peneliti. Karena dibantu oleh komunitas literasi sehingga memudahkan aktifitas yang terus berjalan di taman bacaan masyarakat tersebut. Selain itu bukubuku pun tidak disimpan di tempat lain, melainkan buku-buku yang ada diletakkan di masjid sehingga ketika anak-anak berada di masjid, mereka bisa membaca buku walaupun tanpa kehadiran peneliti dan komunitas literasi.

Dalam pelaksanaan pembangunan taman bacaan masyarakat, yang menjadi target dari tolak ukur itu sendiri adalah dengan adanya kegiatan pembinaan minat bacaan masyarakat yang dilakukan di taman bacaan Dusun Kemasan ini. Kegiatan pembinaan minat baca dilakukan secara terus menerus dengan cara peneliti dan komunitas literasi hadir di taman bacaan untuk mengetahui kondisi bagaimana minat baca anak-anak ketika ada dan atau tanpa adanya peneliti juga komunitas literasi. Oleh karena itu, peneliti selalu mencoba koordinasi dengan masyarakat khususnya informan terkait dengan kondisi anak-anak terutama dalam hal membaca buku dengan ada atau tanpa adanya peneliti dan komunitas literasi apakah pembinaan minat baca yang dilakukan setiap minggu dengan cara memberi motivasi, semangat untuk membaca hingga keuntungan jika rajin membaca memberikan efek yang baik untuk anak-anak atau tidak. Dengan adanya pemantauan langsung yang dilakukan informan.

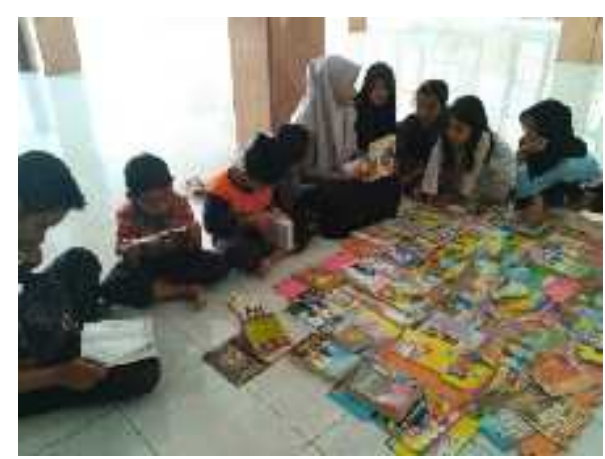

Gambar 4. Kegiatan Pembinaan Minat Baca Masyarakat.

\section{Simpulan}

Pembinaan minat baca masyarakat melalui pembangunan taman bacaan masyarakat di Dusun Kemasan Desa Klepu Kecamatan Pringapus Kabupaten Semarang sudah sejak lama direncanakan oleh kepala dusun yang bermula karena adanya faktor keinginan agar masyarakat Dusun Kemasan khususnya anakanak bisa mendapatkan informasi yang mudah di akses. Saat ini pembangunan taman bacaan masyarakat sudah terlaksana melalui berbagai macam tahap dan proses yang dilaksanakan diantaranya dengan melakukan observasi sebagai tahap awal, kemudian hasil observasi tersebut direfleksikan dan analisis secara mendalam, dipertanyakan, dinilai, dan dikaji ulang sehingga peneliti mendapatkan hasil yang tepat untuk merencanakan pembangunan taman bacaan Masyarakat untuk meningkatkan minat baca.

Atas dasar refleksi tersebut masalah dirumuskan kembali dan tindakan direncanakan dengan terperinci. Setelah melalui refleksi maka perencanaan program pembangunan taman bacaan masyarakat sebagai sarana pembinaan minat baca dirancang oleh peneliti dengan melibatkan beberapa perangkat dusun dan masyarakat dilaksanakan. Setelah perencanan selesai maka selanjutnya adalah tahap pembangunan taman bacaan masyarakat dan proses pembinaan minat baca masyarakat yang dalam pelaksanaannya melibatkan perangkat dusun, masyarakat dan komunitas literasi yang bernama komunitas buku tuntas.

Tahap pembangunan taman bacaan masyarakat dimulai dari sosialisasi kepada masyarakat, penggalangan donasi berupa uang atau barang, dan juga menentukan tempat untuk pembangunannya. 
Setelah tahap pembangunan taman bacaan masyarakat selesai dilanjutkan dengan proses pembinaan minat baca dengan melibatkan komunitas literasi bernama komunitas buku tuntas dari mulai merancang kegiatan sampai pada tahap pelaksanaannya.

Setelah proses pembinaan minat baca dilakukan, masyarakat sangat antusias dan berharap agar taman bacaan masyarakat ini kegiatannya terus berjalan karena masyarakat memiliki harapan agar masyarakat khususnya anak-anak bisa menjadi anak-anak yang baik akhlaknya yaitu terbebas dari pergaulan kenakalan remaja, menjadi anak-anak yang memiliki pengetahuan dan wawasan yang luas dan juga agar anak-anak memiliki sentral belajar untuk pengembangan diri serta belajar tentang keilmuan yang dipelajari di sekolah lebih mendalam.

Tahap dan proses pembinaan minat baca melaui pembangunan taman bacaan masyarakat telah dilaksanakan dimulai dari tahap observasi, refleksi dan perencanaan, pembangunan hingga proses pembinaan minat baca masyarakat yang melibatkan perangkat dusun, masyarakat dan komunitas. Hasil akhirnya adalah dilakukan tahap terakhir yaitu tahap evaluasi secara keseluruhan. Dan hasil dari pembangunan taman bacaan masyarakat sebagai sarana pembinaan minat baca masih belum maksimal. Kegiatannya memang mendapatkan apresiasi yang cukup baik di masyarakat tetapi dalam pengadaan dan pelaksanaannya masih belum memenuhi semua unsur taman bacaan masyarakat yang sempurna sehingga masih perlu dilengkapi kembali segala kebutuhan taman bacaan masyarakatnya. Selain itu dalam pengorganisasisan dan pengelolaannya saat ini masih sederhana. Sehingga kerjasama dengan komunitas literasi adalah salah satu cara tempuh agar kegiatan di taman bacaan bisa terus dijalankan dan mendapatkan ide-ide segar untuk menghidupkan dan mengembangkan aktivitas yang ada di taman bacaan masyarakat.

\section{Daftar Pustaka}

Conyers, Diana. 1991. Perencanaan Sosial di Dunia ketiga. Yogyakarta: UGM Press.

Creswell, John W. 2014. Research Design: Pendekatan Kualitatif, Kuantitatif, dan Mixed. Yogyakarta: Pustaka Pelajar.

Departemen Pendidikan Nasional. Direktorat Jendral Pendidikan Luar Sekolah dan Pemuda. Direktorat pendidikan Masyarakat. 2003. Pedoman Pengelolaan Taman Bacaan Masyarakat (TBM). Jakarta: Departemen Pendidikan Nasional.

Firmansyah. 2009. "Pembangunan Perpustakaan Masyarakat Dengan Patisipasi Masyarakat (Kaji Tindak Partisipatif/Participatory Action Research di Kampung Gunung Batu, Desa Tangkil, Kecamatan Caringin, Kabupaten Bogor, Jawa Barat". Skripsi. S1 Ilmu Perpustakaan dan Informasi. Universitas Indonesia. Jakarta

Indonesia, Undang-undang, Peraturan dsb. Undang-Undang Republik Indonesia Nomor 43 Tahun 2007 Tentang Perpustakaan. Jakarta: Perpustakaan Nasional RI, 2007.

Kementrian Pendidikan Nasional dan Kebudayaan. Direktorat Jendral Pendidikan Anak Usia Dini, Nonformal dan Informal. Direktorat Pembinaan Pendidikan Masyarakat. 2012. Petunjuk Teknis danPengelolaan Bantuan Perluasan dan Penguatan Taman bacaanMasyarakat. Jakarta : Departemen Pendidikan Nasional.

Moeloeng, Lexy J. 1989. Metodologi Penelitian. Bandung: Remadja Karya.

Putra, Nusa. 2014. Penelitian Tindakan. Bandung: PT Remaja Rosdakarya Offset.

Perpustakaan Nasional RI. 2011. Kajian Pembudayaan Kegemaran Membaca. (Jakarta: Perpustakaan Nasional RI, 2011), h.15

Reitz, J. M. 2004. Dictionary for Library and Information Science. Danbury, USA, Libraries Unlimited: 800 .

Rusmana, Agus. 1996. "Pemasaran Perpustakaan dan Pemasaran Jasa."

Sulistyo Basuki. 2006. Metode Penelitian. Jakarta: Wedatama Widya Sastra.

------- 1994. Periodisasi Perpustakaan Indonesia. Bandung: PT Remaja Rosdakarya.

Sugiyono. 2008. Memahami Penelitian Kualitatif. Bandung: ALFABETA.

Sutarno Ns. 2006. Perpustakaan dan Masyarakat. Jakarta. Sagung Seto.

2008. Membina Perpustakaan Desa :Dilengkapi Undang Undang Nomor 43 Tahun 2007

Tentang Perpustakaan. Jakarta : Sagung Seto. 